Journal of Animal and Veterinary Advances 10 (16): 2067-2073, 2011

ISSN: $1680-5593$

(C) Medwell Journals, 2011

\title{
Relationship Between Parity and Cellular Composition of Somatic Cells in Milk of Chinese Holstein Cows
}

\author{
A.B. Yu, G.Q. Zhao, S.Q. Tian and Y.J. Huo \\ Laboratory of Animal Nutrition, College of Animal Science and Technology, \\ Yangzhou University, Yangzhou, P.R. China
}

\begin{abstract}
The present study was made to explore the relationship between the cellular composition of somatic cells in milk of dairy cattles and parity. A total of 75 Chinese Holstein cows (from primiparous to 5 th lactation) from Experimental Farm of Yangzhou University were selected and divided into 5 groups according to parity (15 cows per group). Composition of leukocytes in blood and concentrations of fat, protein, lactose, total solid, Milk Urea Nitrogen (MUN) and Somatic Cells Counts (SCC) in the milk were determined. The ratios of Macrophages (MAC), Polymorphonuclear Neutrophil Leucocytes (PMN) and Lymphocytes (LYM) in milk and peripheral blood were examined using flow cytometry and whether the ratios of the three kinds of cells was influenced by parity of the cow was then analyzed. Results showed that the percentages of MAC, PMN and LYM were $5.72 \sim 7.26,30.10 \sim 41.10$ and $50.65 \% \sim 60.12 \%$ in blood, respectively and showed no significant difference among groups. The somatic cells in milk were mainly composed of MAC, PMN and LYM. The range of MAC, PMN and LYM were 11.47 22.56, 19.48 29.56 and 45.83\% 63.44\%. With the increase of parity, the ratios of MAC and PMN tended to be increased and LYM tended to be decreased. The results suggested that the progressive increase of SCC when parity increased might be likely related to immune mechanisms in absence of infection and resulted from increased secretion of MAC and PMN in udder. The changes of the ratios of different leukocytes to SCC in milk might provide a sensible method of indicating mammary health condition without visible infections and further understanding of generation of SCC in milk in response to parity.
\end{abstract}

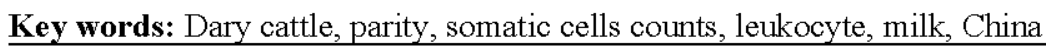

\section{INTRODUCTION}

The presence of cells in bovine milk, so called somatic cells has been recognized and studied for many years. Somatic Cell Count (SCC) is the total number of leukocytes cells per milliliter in milk (Miller et al., 1986). SCC in the milk of a healthy cow is normally $2 \sim 3 \times 10^{5} \mathrm{~mL}^{-1}$ and is often used as an indirect measure of mammary infection status (Shook and Schultz, 1994; Caraviello et al., 2005). These cells originate from blood cells and play an important role in the metabolism of the mammary gland (Burvenich et al., 1994). The majority of the cells in somatic cell counts are leukocytes and others are cells from the udder secretory tissue (epithelial cells) (Bradley and Green, 2005). The epithelial cells are shed and renewed in the normal body processes. The white blood cells serve as a defense mechanism to fight disease infection and assist in repairing damaged tissue (Ma et al., 2000). The white blood cells are mainly composed of Macrophage (MAC), Lymphocyte (LYM) and Polymorphonuclear Neutrophil leukocytes (PMN) (Dosogne et al., 2003; Bradley and Green, 2005).
Morgante et al. (1996) reported the SCC from healthy primiparous Comisana ewes was $56.7 \pm 45.2 \times 10^{3} \mathrm{~mL}^{-1}$ consisting of $30.6 \% \mathrm{PMN}, 57.3 \% \mathrm{MAC}$ and $8.2 \% \mathrm{LYM}$. However, reports about the cellular composition of somatic cells in bovine milk are rare and there is no evidence to indicate the same composition that occurs in ewe's milk occurs in the dairy cow. Paape and Capuco (1997) claimed that neutrophils made up $50-70 \%$ of the somatic cell count in milk from goats free of intramammary infection whereas neutrophils only made up $5-20 \%$ of the total cell count in bovine milk. Milk leukocytes play an important role in defending the mammary gland from aggression of pathogenic microorganisms. The number and relative proportion of each type of leukocyte is influenced by various physiological and pathological states of the udder (Cuccuru et al., 1997).

A lot of factors such as season, parity, lactation stage, nutrition, sanitation, environment, management and genetic factors could influence the level of SCC in bovine milk (Green et al., 2006, 2008; Heuven et al., 1988; Sheldrake et al., 1983). High levels of SCC in milk could result in great loss of milk yield and have negative effect

Corresponding Author: Guoqi Zhao, College of Animal Science and Technology, Yangzhou University, 225009 Yangzhou, China 
on quality, life time and processing traits of milk (Barbano et al., 1991; Jones et al., 1984). SCC is mainly composed of leukocytes produced by the cow's immune system to fight an inflammation in the mammary gland or mastitis. SCC provides an indication of the healthy condition of mammary gland in an individual cow or in the herd if bulk milk is used and it is a hot topic in recent studies.

Previous studies mostly concentrated on the relationship between SCC and the factors that affect their occurrence (Ceron-Munoz et al., 2002; Durr et al., 2008; Rekik et al., 2008; Schepers et al., 1997). Few studies have reported about the cellular composition of SCC secreted from dairy cow mammary. The purpose of the study was to characterize the cellular composition of SCC in milk in related to different parity in dairy cows.

\section{MATERIALS AND METHODS}

Experimental animals: Seventy five healthy Chinese Holstein cows with five different parity (1st-5th lactation) from Experimental Farm of Yangzhou University were selected in the study. Each parity group had 15 cows. Body weight, lactation stage and milking yield of the cow at the beginning of the trial were considered before being selected. Each cow was examined to check for the presence of redness, swelling, hardness or pain in the udder or the presence of clots in the milk to ensure all the animals selected had shown without mastitis. All the cows were housed in the same type of free stall barns and fed the same Total Mixed Ration (TMR) 3 times daily. The cows were milked 3 times daily. Body weight, milking yield and lactation stage were $588.37 \pm 31.21 \mathrm{~kg}$, $22.31 \pm 3.13 \mathrm{~kg} \mathrm{day}^{-1}$ and $29.17 \pm 5.45$ days, respectively.

Milk composition analysis: Duplicate milk samples from each cow (4:3:3 mixture of morning, noon and evening milk by volume) were collected on the sampling day. Samples were collected on 3 continuous days with 3 samples taken per cow. Therefore, total 45 samples of each group were collected for SCC composition analysis and each milk samples $(50 \mathrm{~mL})$ was preserved with potassium dichromate and analyzed for fat, protein, lactose, total solids, Milk Urea Nitrogen (MUN) and Somatic Cell Count (SCC) by using a MilkoScan Minor machine (MilkoScan 4000, Foss Electric, Hillerod, Denmark).

Blood sample and milk sample's collection for flow cytometry analysis: Blood samples were taken before the morning milking at 8.00 am from the coccygeal vein and heparin sodium was used as anticoagulant in the sample tubes. Each sample was $10 \mathrm{~mL}$ in volume and was kept in an ice box prior to delivery to the lab. The $2 \mathrm{~mL}$ of each blood sample was taken and prepared for the analyses of leukocyte composition. The differential leukocyte count milk samples were foremilk samples collected before the morning milking. Each milk sample was $1000 \mathrm{~mL}$ in volume. Blood and milk samples were collected on different sampling day and collected at a time so total 75 samples of blood or milk were collected for cytmetry analysis.

Blood sample and milk sample's preparation for flow cytometry analysis: Preparation of each blood sample was as follows: Isolation of somatic cells (including white and red cells) and cell counting: $2 \mathrm{~mL}$ blood sample was layered on $20 \mathrm{~mL}$ of PBS in a $50 \mathrm{ML}$ centrifuge tube and centrifuged at $2300 \times \mathrm{g}$ for $15 \mathrm{~min}$ at $4^{\circ} \mathrm{C}$ and the supernatant was subsequently discarded. This operation was repeated 2-3 times to isolate and recover the total cell pellets of blood sample. After dilution with $1 \mathrm{~mL}$ PBS, the cells were percolated with a 400 mesh strainer to perform a microscopic slide cell count (Olympus CKX41); rinse with buffer and labeling: Suspended the cells with $1 \mathrm{~mL}$ PBS and $1 \mathrm{~mL} 10 \%$ bovine serum (Fetal bovine serum, FBS) then centrifuged at $2300 \times \mathrm{g}$ for $15 \mathrm{~min}$ at $4^{\circ} \mathrm{C}$ and the supernatant was subsequently discarded. Blotted $400 \mu \mathrm{L}$ cell deposition into $1.5 \mathrm{~mL}$ centrifuge tube, suspended with $1 \mathrm{~mL}$ PBS and $1 \mathrm{~mL} \mathrm{10 \%} \mathrm{bovine} \mathrm{serum} \mathrm{and} \mathrm{after} \mathrm{that}$ the cells were labeled with $10 \mu \mathrm{L}$ CD14 (FITC MCA2678F AbD Serotec) and $10 \mu \mathrm{L}$ CD45 (RPE MA1-81458 Thermo Scientific) at the same time. They were incubated for $40 \mathrm{~min}$ and then centrifuged at $2300 \times \mathrm{g}$ for $15 \mathrm{~min}$ at $4^{\circ} \mathrm{C}$; deterioration of red cells and rinse of white cells: $1 \mathrm{~mL}$ erythrocyte lysate was added to the cell pellets and centrifuged at $2300 \times \mathrm{g}$ for $15 \mathrm{~min}$ at $4^{\circ} \mathrm{C}$ after $20 \mathrm{~min}$ incubation. The cell deposition was rinsed $3 \sim 4$ times with $1 \mathrm{~mL}$ PBS for further flow cytometric sorting (BD FACSCalibur).

Preparation of each milk sample was similar to the preparation of blood sample. But before that of it, each milk sample $(200 \mathrm{~mL})$ collected from each cow was centrifuged at $4500 \times \mathrm{g}$ for $20 \mathrm{~min}$ at $4^{\circ} \mathrm{C}$ to remove the fat.

Flow cytometry and cell sorting: Flow cytometry identification of cells based on forward and side scatter is difficult because cellular debris may interfere with the scatter pattern of normal cells. This is especially true for bovine milk involved with impurity substances and phagocytosis of milk components may alter both size and intracellular granularity. Therefore, fluorescent labeling techniques with monoclonal antibodies CD45 (RPe) and 
CD14 (FITC) have been developed based on a previous study (Dosogne et al., 2003) to differentiate leukocytes in both blood and milk.

A flow cytometer (BD FACSCalibur) equipped with an argon ion laser was used for determining the differential leukocyte count. The excitation wavelength of the laser was 495 and $565 \mathrm{~nm}$. The forward scatter signal was amplified before side scatter and fluorescence signals were not amplified. The signal was measured with a band-pass filter and registered on a log scale. The leukocyte could be classified as LYM, PMN and MAC based on the size, inner complex structure of the cell pellets and intensity of fluorescence of different wavelengths.

Statistical analysis: Results were expressed as means \pm standard errors of the means. The data were analyzed by one-way ANOVA and a Duncan's test was used to determine the statistical significance of differences between parity groups of cows. High and mostly high significance levels were assumed at $\mathrm{p}<0.05$ and $\mathrm{p}<0.01$, respectively.

\section{RESULTS AND DISCUSSION}

Milk composition: A total of 225 samples were analyzed for milk composition. The results are shown in Table 1. It was shown that the parity did not influence the percent fat, protein, total solid and MUN in milk during the early lactation significantly. But the percent of lactose of primiparous was significantly higher than that of multiparous $(p<0.05)$. When the relationship between milk SCC and parity was compared, data showed that SCC was markedly increased as parity rose. Meanwhile, milk SCC of primiparous was significantly lower than that of 4th and 5 th parity $(\mathrm{p}<0.05)$.

Categorization of leukocytes in blood and milk: Leukocytes cells were isolated from peripheral blood and milk for the flow cytometric cell sorting procedure. To better characterize the leukocyte cells, researchers experimented to find the appropriate antibody and labeling condition or circumstance through the trial. Flow cytometric differential leukocyte count of samples after

Table 1: Composition of milk from cows in relation to parity Parity $^{1}$

\begin{tabular}{|c|c|c|c|c|c|c|}
\hline Items & $1 \mathrm{st}$ & 2nd & $3 \mathrm{rd}$ & 4th & 5 th & $\mathrm{SEM}^{2}$ \\
\hline Fat (\%) & 3.68 & 3.75 & 3.80 & 3.92 & 3.92 & 0.05 \\
\hline Protein $(\%)$ & 3.30 & 3.32 & 3.33 & 3.25 & 3.42 & 0.03 \\
\hline Lactose $(\%)$ & $5.04^{\mathrm{a}}$ & $4.76^{b}$ & $4.74^{\mathrm{b}}$ & $4.72^{\mathrm{b}}$ & $4.70^{b}$ & 0.02 \\
\hline Total solid (\%) & 13.12 & 13.10 & 13.09 & 13.21 & 13.20 & 0.07 \\
\hline $\operatorname{MUN}\left(\mathrm{mg} \mathrm{dL}^{-1}\right)$ & 15.01 & 14.44 & 14.30 & 14.57 & 14.87 & 0.34 \\
\hline $\mathrm{SCC} \times 10^{3}$ & $265.29^{\mathrm{a}}$ & $367.90^{\mathrm{ab}}$ & $374.58^{\mathrm{ab}}$ & $449.50^{b}$ & $456.26^{b}$ & 22.76 \\
\hline
\end{tabular}

${ }^{a}$, b Means within a row with different superscripts differ $(p<0.05)$. ${ }^{1}$ Parity: Samples were collected from 5 different parity herds on 3 continuous days with 3 samples taken per cow. Total $225(=15 \times 5 \times 3)$ samples included for analy sis. ${ }^{2} \mathrm{SEM}=$ Standard Error of the Mean antibody labeling was quantified using fluorescence dot plot. Three different cell types were separated obviously in different regions in both blood and milk sample analysis results. MAC (P2), PMN (P3) and L YM (P4) were defined as main cell types in blood and LYM (P3), MAC (P4), $\mathrm{PMN}$ (P5) in milk. In addition, epithelial cell in both blood and milk could not be separated through this method. Flow cytometric analysis results of blood and milk are shown in Fig. 1 and 2, respectively.

Composition of leukocytes in blood: The proportion of MAC in peripheral blood obtained from different parity of cows ranged from $5.72-7.26 \%$. The proportion of PMN ranged from $30.10-41.10 \%$ and LYM varied from $50.65-60.12 \%$. The percent of MAC, LYM and PMN was relatively stable and showed no significant difference within each of the parities ( $>>0.05)$.

Composition of leukocytes in milk: Analysis results of the leukocyte composition in milk showed differences in variation compared to that of blood. The proportion of $\mathrm{MAC}$ in milk ranged from $11.47-22.56 \%$ and showed increasing trend in line with the parity. Percent of MAC on SCC in 1st parity was mostly low than that of 4th and 5 th parity $(p<0.01)$. The ratio of $\mathrm{MAC}$ in 2 nd was significantly $<4$ and 5 th parity at the same time $(\mathrm{p}<0.05)$. The proportion of PMN ranged from 19.48-29.56\% and showed an increasing trend along with the parity and reached maximum on 5th parity. It was showed that percent of $\mathrm{PMN}$ in primiparous was low significantly than 4th parity $(\mathrm{p}<0.05)$ as well as mostly low than that of 5 th parity $(\mathrm{p}<0.01)$. The proportion of LYM varied from $45.83-63.44 \%$. The percent of LYM tended to decrease with increasing parity and reached a minimum value on the 4th parity. Value of LYM in primiparous cattle was mostly high than 5 th parity $(\mathrm{p}<0.01)$ and showed a significant difference to 4 th parity $(\mathrm{p}<0.05)$. In addition, values between 2 nd and 5th parity also showed significant difference $(\mathrm{p}<0.05)$.

The result of this study suggested that parity of cows almost did not affect the traits of milk but SCC and elevation of parity will be result in an increase of SCC. This result was agreed with Wilson et al. (1995) and Dulin et al. (1983) which reported that with increasing parity the somatic cell count in milk also increased in dairy cows. Zeng and Escobar (1995) also claimed that parity of goats did not affect variables of composition of milk including percent fat, percent protein, percent lactose, percent solids non-fat and SCC except for milk production. However, Laevens et al. (1997) reported that significant effects of parity on SCC in milk could not be found when only bacteriologically negative cows were considered. Thus, the effect of parity on variation of SCC was likely due to incidental factors such as mastitis infections, just 

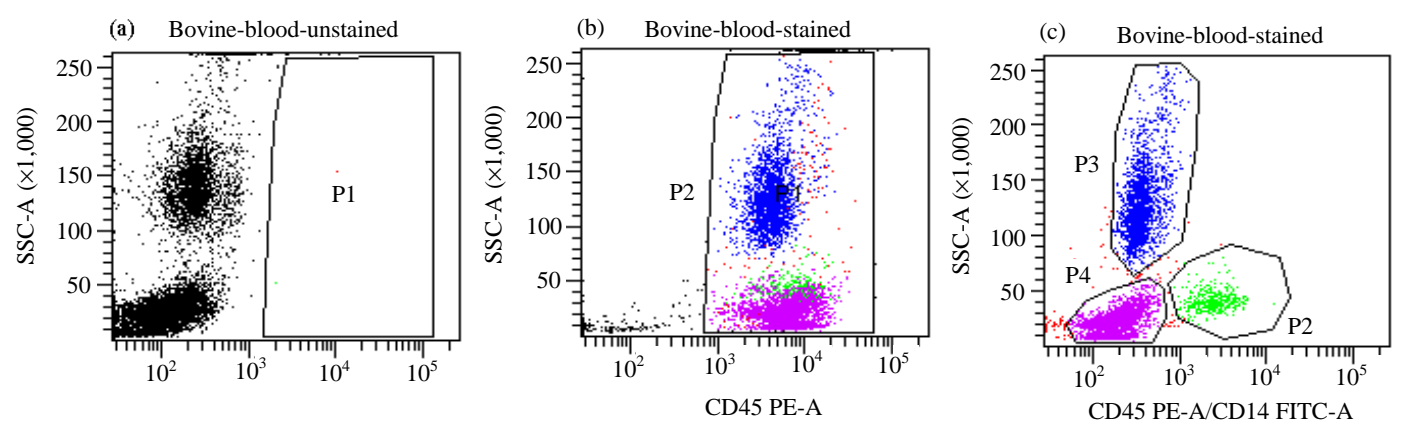

Fig. 1: Flow cytometric analysis of fluorescence antibody labeled bovine blood cells. (a) All leukocytes were unlabeled and all of them located outside the gate P1. (b) All leukocytes were labeled with CD45. This resulted in the increased intensity of fluorescence of cells with the cells mainly in gate P1 area and only few impurity substances or segment of cells remained outside of the gate and were in the district P2. Blue fluorescence showed PMN has been isolated from leukocytes based on Side Scatter (SSC) of flow cytometric cell sorting. (c) All leukocytes were labeled with CD45 and CD14 and MAC was labeled with CD14 specifically. Subsequently, leukocytes were distributed in three areas P2 (MAC), P3 (PMN) and P4 (LYM), distinctively
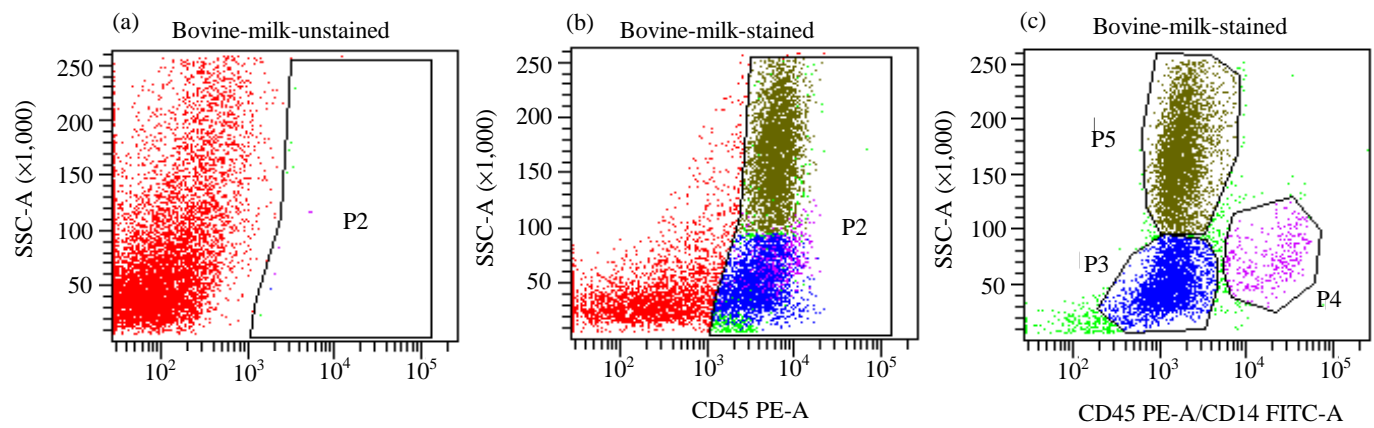

Fig. 2: Flow cytometric analysis of fluorescence antibody labeled bovine milk somatic cells. (a) All leukocytes were unlabeled and all of them located outside the gate P2. (b) All leukocytes were labeled with CD45. This resulted in the increased intensity of fluorescence of cells and with the cells mainly in gate $\mathrm{P} 2$ area. Yellow fluorescence showed PMN has been isolated from leukocytes based on Side Scatter (SSC) of flow cytometric cell sorting. (c) All leukocytes were labeled with CD45 and CD14 and MAC was labeled with CD14 specifically. Subsequently, leukocytes were distributed in three areas P3 (LYM), P4 (MAC) and P5 (PMN), distinctively

as Heuven et al. (1988) claimed the increase of SCC over parities shows that older cows were more likely to suffer prolonged elevation of SCC or even permanent udder damage. High SCC of older cows in milk could also be explained by physiological reduction of milk yield (Cuccuru et al., 1997). Therefore, in order to learn more about the reason of rising of SCC over parities, it was necessary to classify the composition of somatic cells in milk.

It is generally considered that somatic cells of milk originate from the blood and the number, differential count and function of leukocytes within the mammary gland could contribute to the defense against invading pathogens (Mullarky et al., 2001; Zecconi et al., 1994). $\mathrm{PMN}$ are produced in the bone marrow and migrate into body tissues constituting a physiologic barrier to microbial invasion. There, they phagocytize, kill and digest bacteria in a complex but sophisticated manner utilizing energy and granular constituents (Morgante et al., 1996). During this process PMN also release certain agents which by themselves are inflammatory (Jones et al., 1984). As physiological and environmental factors have a smaller influence on the number of PMN in milk (Jones et al., 1984) since the increase is related strictly to the presence of microorganisms in the mammary gland (Cuccuru et al., 1997).

Therefore, the increase percent of PMN in milk observed in this study confirms the woresen of mammary inflammation in older cows without visiable mastitis. Considering the count of somatic cells in milk was increased with parity, the amount of PMN secreted cells in the mammary gland of older dairy cows was relatively huge. Increased levels of somatic cell counts in older cows could be explained by remarkable increase of PMN to some extent (Fig. 3). 

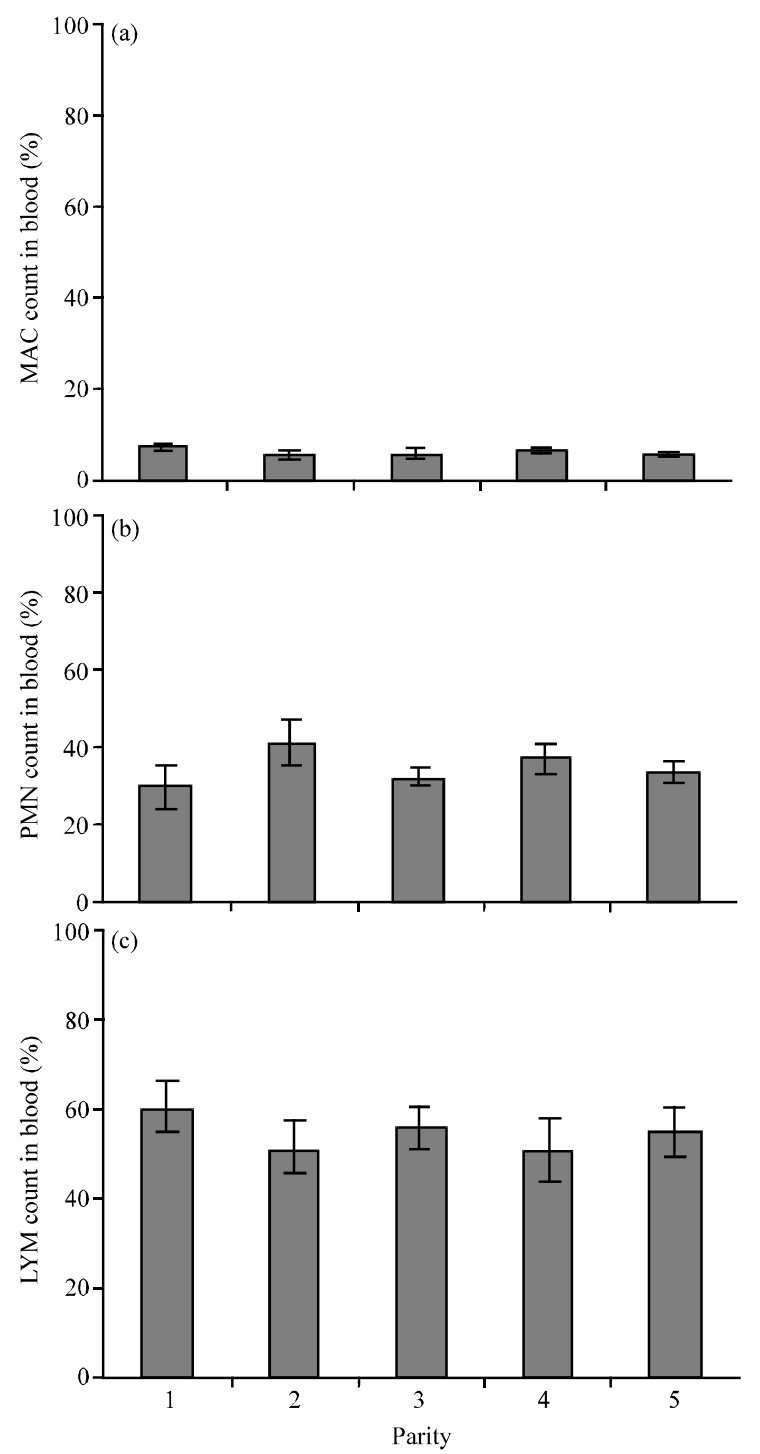

Fig. 3a-c: Differential blood leukocyte percent for cows ( $\mathrm{n}=75$ ) without clinical sings of mastitis in relation to parity. The bars have no markers means the group have no significant difference $(p>0.05)$ at the $95 \%$ confidence interval with two tail t-test

The study found that MAC constituted an important percentage of the somatic cells in milk and was more abundant in milk than that in blood. Furthermore, the level of MAC in milk was increased in multiparous cattle. It could be hypothesized that the higher level of MAC in milk than blood was associated with mobilization of MAC which permeated from blood to the mammary gland through blood capillaries. But the evaluation of dynamics of MAC needs further research. The exact role of MAC in the mammary gland secretions with respect to resistance to mastitis has also not been clearly elucidated.
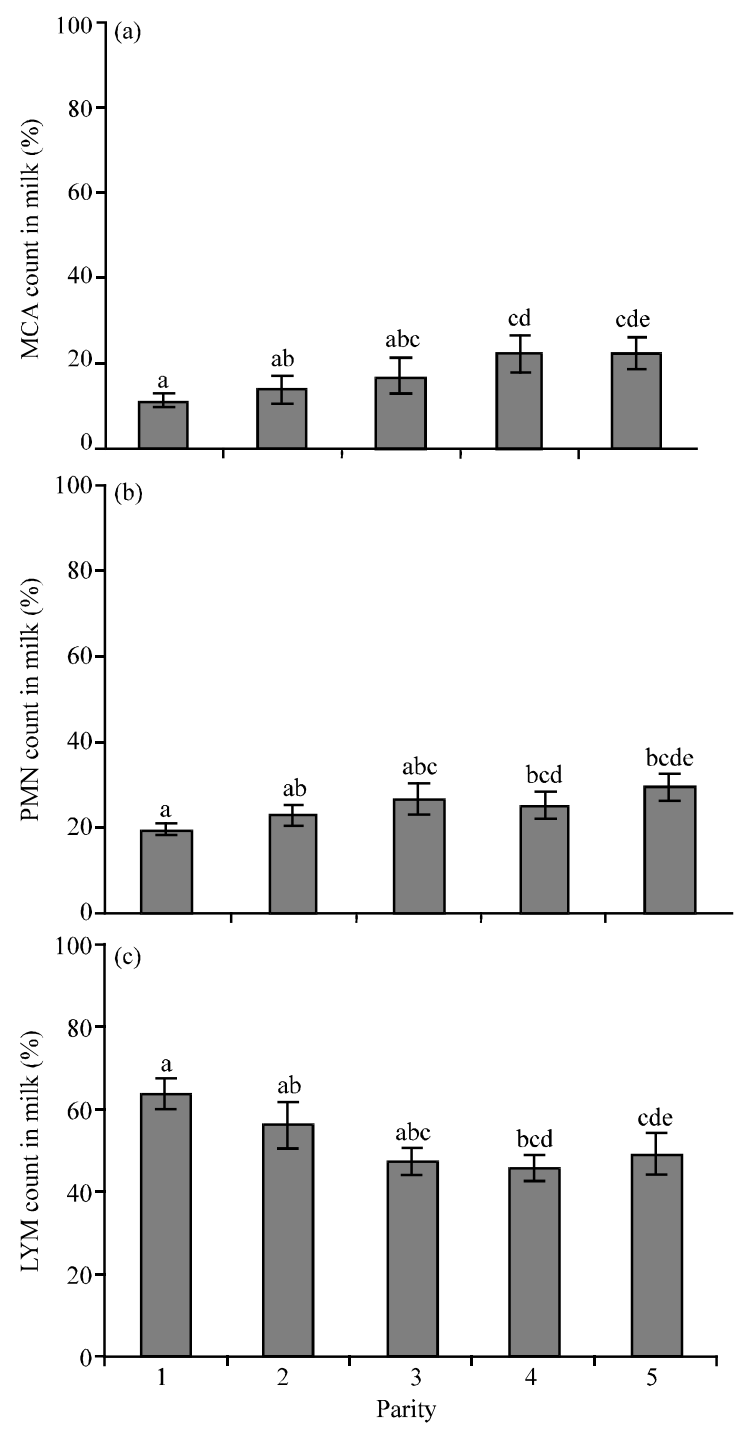

Fig. 4a-c: Differential milk leukocyte percent for cows (n $=75$ ) without mastitis in relation to parity. a-e, the bars with different letters marked means have significant between the groups $(\mathrm{p}<0.05)$ and the bars marked have same letters means the group have no significant difference at the $95 \%$ confidence interval with two tail t-test

Denis et al. (2006) reported that milk MAC from lactating cows did not exert bactericidal activity against $S$. uberis and released low quantities of TNF-a in response to this pathogen. Conversely, Sordillo et al. (1987) claimed that MAC in mammary gland could secret cytokine and leukotriene that were able to induce PMN movement from blood into mammary gland. Both MAC and PMN were increased in bovine milk in relation to parity in the study was in agreement with this point (Fig. 4).

LYM included T cells, B cells and NK cells which have their own killing ability and secreting of antibody to 
defend, kill and clear pathogenic bacteria (Mullarky et al., 2001). In fact, the percent of LYM in milk was observed decrease with increasing parity in the study. For migratory population of LYM is being selectively recruited to the mammary gland from the peripheral and infiltration of the mammary gland by LYM is closely related to the immune response (Harp et al., 2004). In addition, L YM vary in cell populations and their release of important cytokines can influence the immune response and the susceptibility to disease (Meglia el al., 2005). This finding indicated an older cow could have poorer udder immunity status as compared to a primiparous one.

The variation of leukocyte cellular composition of blood covered a narrower field compared to that of milk and showed no significant difference between each of the parities. In other words, the composition of $M A C, P M N$ and LYM in blood was relatively stable and influenced by few factors. In fact, it has been observed that the proportion of MAC on SCC in milk was mostly high than that in blood and the proportion of PMN and LYM was low than that in blood on contrary. What's the relationship between in milk and in blood as leukocyte cellular composition concerned has rare been reported. Burvenich et al. (1994) reported that with the acceleration of apoptosis of MAC and LYM in blood of bovine, the susceptibility to disease increases at the same time and more PMN is secreted in blood to resist pathogenic bacteria. But the mechanism of this phenomenon has not been clearly explained and need more evaluation.

\section{CONCLUSION}

The Macrophage (MAC), Polymorphonuclear Neutrophil (PMN) and Lymphocyte (LYM) in peripheral blood and milk of healthy cows were separated through fluorescence antibody labeling using flow cytomety. The composition of leukocytes in peripheral blood had no relation to parity in statistics but that of milk was markedly influenced by parity. With increasing of parity, the levels of PMN and MAC showed a tendency to be increased and LYM showed a decreasing trend in milk. Because of a limited numbers of cows recruited in the study, additional research is needed.

\section{REFERENCES}

Barbano, D.M., R.R. Rasmussen and J.M. Lynch, 1991. Influence of milk somatic cell count and milk age on cheese yield. J. Dairy Sci., 74: 369-388.

Bradley, A. and M. Green, 2005. Use and interpretation of somatic cell count data in dairy cows. Practice, 27: 310-315.
Burvenich, C., M.J. Paape, A.W. Hill, A.J. Guidry and R.H. Miller et al., 1994. Role of the neutrophil leucocyte in the local and systemic reactions during experimentally induced $E$. coli mastitis in cows immediately after calving. Vet. Q., 16: 45-49.

Caraviello, D.Z., K.A. Weigel, G.E. Shook and P.L. Ruegg, 2005. Assessment of the impact of somatic cell count on functional longevity in holstein and jersey cattle using survival analysis methodology. J. Dairy Sci., 88: 804-811.

Ceron-Munoz, M., H. Tonhati, J. Duarte, J. Oliveira, M. Munoz-Berrocal and H. Jurado-Gamez, 2002. Factors affecting somatic cell counts and their relations with milk and milk constituent yield in buffaloes. J. Dairy Sci., 85: 2885-2889.

Cuccuru C., P. Moroni, A. Zecconi, S. Casu, A. Caria and A. Contini, 1997. Milk differential cell counts in relation to total counts in Sardinian ewes. Small Rumin. Res., 25: 169-173.

Denis, M., N.A. Parlane, S.J. Lacy-Hulbert, E.L. Summers, B.M. Buddle and D.N. Wedlock, 2006. Bactericidal activity of macrophages against Streptococcus uberis is different in mammary gland secretions of lactating and drying off cows. Vet. Immunol. Immunopathol., 114: 111-120.

Dosogne, H., F. Vangroenweghe, J. Mehrzad, A.M. Massart-Leën and C. Burvenich, 2003. Differential leukocyte count method for bovine low somatic cell count milk. J. Dairy Sci., 86: 828-834.

Dulin, A.M., M.J. Paape, W.D. Schultze and B.T. Weinland, 1983. Effect of parity, stage of lactation and intramammary infection on concentration of somatic cells and cytoplasmic particles in goat milk. J. Dairy Sci., 66: 2426-2433.

Durr, J.W., R.I. Cue, H.G. Monardes, J. Moro-Mendez and K.M. Wade, 2008. Milk losses associated with somatic cell counts per breed, parity and stage of lactation in Canadian dairy cattle. Livest. Sci., 117: 225-232.

Green, M.J., A.J. Bradley, G.F. Medley and W.J. Browne, 2008. Cow, farm and herd management factors in the dry period associated with raised somatic cell counts in early lactation. J. Dairy Sci., 91: 1403-1415.

Green, M.J., A.J. Bradley, H. Newton and W.J. Browne, 2006. Seasonal variation of bulk milk somatic cell counts in UK dairy herds: Investigations of the summer rise. Prev. Vet. Med., 74: 293-308.

Harp, J.A., T.E. Waters and J.P. Goff, 2004. Lymphocyte subsets and adhesion molecule expression in milk and blood of periparturient dairy cattle. Vet. Immunol. Immunopathol., 102: 9-17.

Heuven, H.C.M., H. Bovenhuis and R.D. Politiek, 1988. Inheritance of somatic cell count and its genetic relationship with milk yield in different parities. Livest. Prod. Sci., 18: 115-127. 
Jones, G.M., R.E. Pearson, G.A. Clabaugh and C.W. Heald, 1984. Relationships between somatic cell counts and milk production. J. Dairy Sci., 67: 1823-1831.

Laevens, H., H. Deluker, Y.H. Schukken, L. de Meulemeester, R. Vandermeersch, D. Muelenaere and A.E. Kruif, 1997. Influence of parity and stage of lactation on the somatic cell count in bacteriologically negative dairy cows. J. Dairy Sci., 80: 3219-3226.

Ma, Y., C. Ryan, D.M. Barbano, D.M. Galton, M.A. Rudan and K.J. Boor, 2000. Effects of somatic cell count on quality and shelf-life of pasteurized fluid milk. J. Dairy Sci., 83: 264-274.

Meglia, G.E., A. Johannisson, S. Agnas, K. Holtenius and W.K. Persson, 2005. Effects of feeding intensity during the dry period on leukocyte and lymphocyte sub-populations, neutrophil function and health in periparturient dairy cows. The Vet. J., 169: 376-384.

Miller, R.H., M.J. Paape and J.C. Acton, 1986. Comparison of milk somatic cell counts by coulter and fossomatic counters. J. Dairy Sci., 69: 1942-1946.

Morgante, M., S. Ranucci, M. Pauselli, C. Casoli and E. Duranti, 1996. Total and differential cell count in milk of primiparous Comisana ewes without clinical signs of mastitis. Small Rumin. Res., 21: 265-271.

Mullarky, I.K., C. Su, N. Frieze, Y.H. Park and L.M. Sordillo1, 2001. Staphylococcus aureus agr genotypes with enterotoxin production capabilities can resist neutrophil bactericidal activity. Infect. Immunity, 69: 45-51.

Paape, M.J. and A.V. Capuco, 1997. Cellular defense mechanisms in the udder and lactation of goats. J. Anim. Sci., 75: 556-565.
Rekik, B., N. Ajili, H. Belhani, A. ben Gara and H. Rouissi, 2008. Effect of somatic cell count on milk and protein yields and female fertility in Tunisian Holstein dairy cows. Livest. Sci., 116: 309-317.

Schepers, A.J., T.J. Lam, Y.H. Schukken, J.B. Wilmink and W.J. Hanekamp, 1997. Estimation of variance components for somatic cell counts to determine thresholds for uninfected quarters. J. Dairy Sci., 80: 1833-1840.

Sheldrake, R.F., R.J.T. Hoare and G.D. McGregor, 1983. Lactation stage, parity and infection affecting somatic cells, electrical conductivity and serum albumin in milk. J. Dairy Sci., 55: 542-547.

Shook, G.E. and M. Schultz, 1994. Selection on somatic cell score to improve resistance to mastitis in the United States. J. Dairy Sci., 77: 648-658.

Sordillo, L.M., S.C. Nickerson, R.M. Akers and S.P. Oliver, 1987. Secretion composition during bovine mammary involution and the relationship with mastitis. Int. J. Biochem., 19: 1165-1172.

Wilson D.J., K.N. Stewart and P.M. Sears, 1995. Effects of stage of lactation, production, parity and season on somatic cell counts in infected and uninfected dairy goats. Small Rumin. Res., 16: 165-169.

Zecconi, A., V. Bronzo, R. Piccinini, G. Spreafico and G. Ruffo, 1994. Phagocytic activity of bovine polymorphonuclear neutrophil leucocytes. J. Dairy Res., 61: 271-279.

Zeng, S.S. and E.N. Escobar, 1995. Effect of parity and milk production on somatic cell count, standard plate count and composition of goat milk. Small Rumin. Res., 17: 269-274. 